\title{
Phytoplankton as Key Mediators of the Biological Carbon Pump: Their Responses to a Changing Climate
}

\author{
Samarpita Basu * (1) and Katherine R. M. Mackey \\ Earth System Science, University of California Irvine, Irvine, CA 92697, USA; kmackey@uci.edu \\ * Correspondence: basusamarpita@gmail.com
}

Received: 7 January 2018; Accepted: 12 March 2018; Published: 19 March 2018

\begin{abstract}
The world's oceans are a major sink for atmospheric carbon dioxide $\left(\mathrm{CO}_{2}\right)$. The biological carbon pump plays a vital role in the net transfer of $\mathrm{CO}_{2}$ from the atmosphere to the oceans and then to the sediments, subsequently maintaining atmospheric $\mathrm{CO}_{2}$ at significantly lower levels than would be the case if it did not exist. The efficiency of the biological pump is a function of phytoplankton physiology and community structure, which are in turn governed by the physical and chemical conditions of the ocean. However, only a few studies have focused on the importance of phytoplankton community structure to the biological pump. Because global change is expected to influence carbon and nutrient availability, temperature and light (via stratification), an improved understanding of how phytoplankton community size structure will respond in the future is required to gain insight into the biological pump and the ability of the ocean to act as a long-term sink for atmospheric $\mathrm{CO}_{2}$. This review article aims to explore the potential impacts of predicted changes in global temperature and the carbonate system on phytoplankton cell size, species and elemental composition, so as to shed light on the ability of the biological pump to sequester carbon in the future ocean.
\end{abstract}

Keywords: phytoplankton; biological carbon pump; climate change; $\mathrm{CO}_{2}$; marine carbon cycle

\section{Introduction}

Marine phytoplankton perform half of all photosynthesis on Earth [1,2] and directly influence global biogeochemical cycles and the climate, yet how they will respond to future global change is unknown. Carbon dioxide $\left(\mathrm{CO}_{2}\right)$ is one of the principal drivers of global change and has been identified as one of the major challenges in the 21st century [3]. $\mathrm{CO}_{2}$ generated during anthropogenic activities such as deforestation and burning of fossil fuels for energy generation rapidly dissolves in the surface ocean and lowers seawater $\mathrm{pH}$, while $\mathrm{CO}_{2}$ remaining in the atmosphere increases global temperatures and leads to increased ocean thermal stratification. While $\mathrm{CO}_{2}$ concentration in the atmosphere is estimated to be about $270 \mathrm{ppm}$ before the industrial revolution, it has currently increased to about $400 \mathrm{ppm}$ [4] and is expected to reach $800-1000 \mathrm{ppm}$ by the end of this century according to the "business as usual" $\mathrm{CO}_{2}$ emission scenario [5].

Marine ecosystems are a major sink for atmospheric $\mathrm{CO}_{2}$ and take up similar amount of $\mathrm{CO}_{2}$ as terrestrial ecosystems, currently accounting for the removal of nearly one third of anthropogenic $\mathrm{CO}_{2}$ emissions from the atmosphere [4,5]. The net transfer of $\mathrm{CO}_{2}$ from the atmosphere to the oceans and then sediments, is mainly a direct consequence of the combined effect of the solubility and the biological pump [6]. While the solubility pump serves to concentrate dissolved inorganic carbon $\left(\mathrm{CO}_{2}\right.$ plus bicarbonate and carbonate ions) in the deep oceans, the biological carbon pump (a key natural process and a major component of the global carbon cycle that regulates atmospheric $\mathrm{CO}_{2}$ levels) transfers both organic and inorganic carbon fixed by primary producers (phytoplankton) in 
the euphotic zone to the ocean interior and subsequently to the underlying sediments [6,7]. Thus, the biological pump takes carbon out of contact with the atmosphere for several thousand years or longer and maintains atmospheric $\mathrm{CO}_{2}$ at significantly lower levels than would be the case if it did not exist [8]. An ocean without a biological pump, which transfers roughly $11 \mathrm{Gt} \mathrm{C} \mathrm{yr}^{-1}$ into the ocean's interior, would result in atmospheric $\mathrm{CO}_{2}$ levels $\sim 400$ ppm higher than present day $[9,10]$.

Understanding the response of the biological carbon pump to global change is required to accurately predict future atmospheric $\mathrm{CO}_{2}$ concentrations [11]. Oceans are projected to undergo significant changes due to the rising atmospheric $\mathrm{CO}_{2}$ levels. The dissolution of anthropogenic $\mathrm{CO}_{2}$ in the ocean and the subsequent formation of carbonic acid has already resulted in a 30\% increase in $\left[\mathrm{H}^{+}\right]$concentration in seawater (resulting in a decrease of $0.1 \mathrm{pH}$ unit and will continue to lower $\mathrm{pH}$ by an additional $0.2-0.3 \mathrm{pH}$ units by the end of the century. This decline in ocean $\mathrm{pH}$ is referred to as ocean acidification [12]. At the same time, warming will increase the mean surface temperatures by an average of $3{ }^{\circ} \mathrm{C}$, leading to longer periods of stratification with fewer deep mixing events $[13,14]$. Increased stratification is expected to lead to nutrient limitation and an increase in average irradiance in the euphotic layer, where phytoplankton grow [5,15] (Figure 1). Phytoplankton are a highly diverse group of microscopic photosynthesizing microalgae and cyanobacteria which act as a link to couple atmospheric and oceanic processes [16]. They contribute nearly $50 \%$ to the total primary production of Earth by fixing about $50 \mathrm{Gt}$ carbon per annum [1].

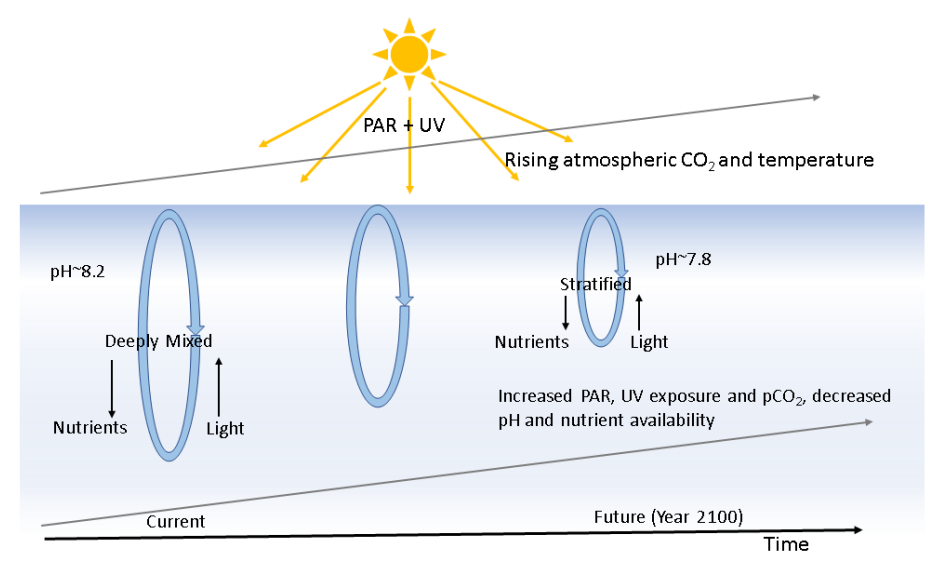

Figure 1. Global change effects on the surface ocean: By the year 2100, $\mathrm{pH}$ of the ocean will decline to 7.8 due to increased uptake of atmospheric $\mathrm{CO}_{2}$. Concomitantly, increased thermal stratification will trap phytoplankton in the surface ocean, resulting in increased light exposure and lower nutrient availability to the cells (adapted from ref. [4]).

The efficiency of the biological pump is a function of phytoplankton physiology and community structure, which are in turn governed by the physical and chemical conditions of the ocean [16]. Ocean acidification can potentially affect phytoplankton community composition and lead to physiological and evolutionary changes in their constituent species [17]. The eco-physiological characteristics of the species in the phytoplankton community regulate the quality (elemental and biochemical composition) and quantity of primary production that is eventually transferred up the food web and exported to the deep ocean and sediment via the biological pump. Despite its critical importance, the role of phytoplankton community structure in modulating the biological pump is poorly understood and is often a neglected component in carbon-climate research [18]. Thus, an increased understanding of how phytoplankton community size structure will respond to ocean acidification and global change is required to gain insight into the biological pump and the ability of the ocean to serve as a long-term sink for atmospheric $\mathrm{CO}_{2}$. In this review article, we first provide background on the biological carbon pump and then review studies aimed at understanding how global changes in temperature, the carbonate system, light intensity and nutrients affect phytoplankton 
physiology and community composition, in an attempt to understand the ability of the biological pump to sequester carbon in the future ocean.

\section{Components of the Biological Carbon Pump: Role of Marine Phytoplankton}

The biological carbon pump is one of the chief determinants of the vertical distribution of carbon in the oceans and therefore of the surface partial pressure of $\mathrm{CO}_{2}$ governing air-sea $\mathrm{CO}_{2}$ exchange [19]. It comprises phytoplankton cells, their consumers and the bacteria that assimilate their waste and plays a central role in the global carbon cycle by delivering carbon from the atmosphere to the deep sea, where it is concentrated and sequestered for centuries [7]. Photosynthesis by phytoplankton lowers the partial pressure of $\mathrm{CO}_{2}$ in the upper ocean, thereby facilitating the absorption of $\mathrm{CO}_{2}$ from the atmosphere by generating a steeper $\mathrm{CO}_{2}$ gradient [20]. It also results in the formation of particulate organic carbon (POC) in the euphotic layer of the epipelagic zone (0-200 m depth). The POC is processed by microbes, zooplankton and their consumers into fecal pellets, organic aggregates ("marine snow") and other forms, which are thereafter exported to the mesopelagic (200-1000 m depth) and bathypelagic zones by sinking and vertical migration by zooplankton and fish (Figure 2) [21]. Although primary production includes both dissolved and particulate organic carbon (DOC and POC respectively), only POC leads to efficient carbon export to the ocean interior, whereas the DOC fraction in surface waters is mostly recycled by bacteria [22]. However, a more biologically resistant DOC fraction produced in the euphotic zone (accounting for 15-20\% of net community productivity), is not immediately mineralized by microbes and accumulates in the ocean surface as biologically-semi labile DOC [23]. This semi-labile DOC undergoes net export to the deep ocean, thus constituting a dynamic part of the biological carbon pump [24]. The efficiency of DOC production and export varies across oceanographic regions, being more prominent in the oligotrophic subtropical oceans [25]. Because the overall efficiency of the biological carbon pump is mostly controlled by the export of POC [22], we focus on this fraction of the organic carbon pool in this review.

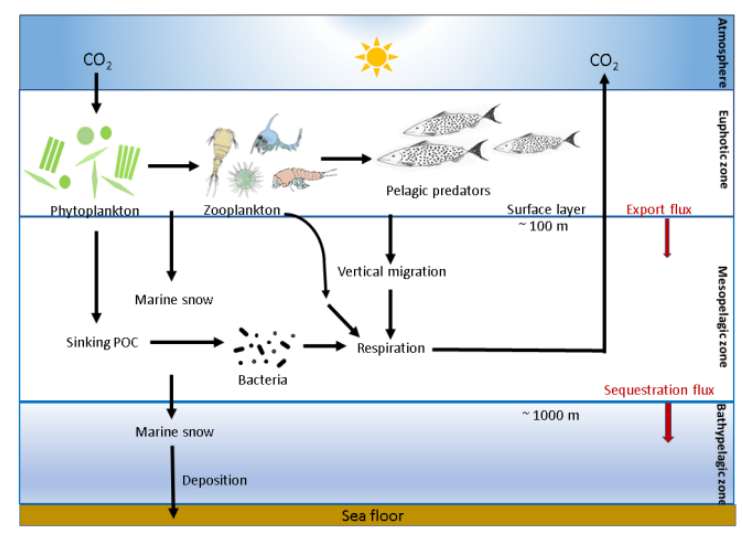

Figure 2. Schematic of the biological carbon pump: Phytoplankton fix $\mathrm{CO}_{2}$ in the euphotic zone using solar energy and produce particulate organic carbon (POC). POC formed in the euphotic zone is processed by microbes, zooplankton and their consumers into organic aggregates (marine snow), which is thereafter exported to the mesopelagic (200-1000 m depth) and bathypelagic zones by sinking and vertical migration by zooplankton and fish. Export flux is defined as the sedimentation out of the surface layer (at approximately $100 \mathrm{~m}$ depth) and sequestration flux is the sedimentation out of the mesopelagic zone (at approximately $1000 \mathrm{~m}$ depth). A portion of the $\mathrm{POC}$ is respired back to $\mathrm{CO}_{2}$ in the oceanic water column at depth, mostly by heterotrophic microbes and zooplankton, thus maintaining a vertical gradient in concentration of dissolved inorganic carbon (DIC). This deep-ocean DIC returns to the atmosphere on millennial timescales through thermohaline circulation. Between $1 \%$ and $40 \%$ of the primary production is exported out of the euphotic zone, which attenuates exponentially towards the base of the mesopelagic zone and only about $1 \%$ of the surface production reaches the sea floor (adapted from ref. [11,21]). 
Passow and Carlson [11] defined sedimentation out of the surface layer (at approximately $100 \mathrm{~m}$ depth) as the "export flux" and that out of the mesopelagic zone (at approximately $1000 \mathrm{~m} \mathrm{depth}$ ) as the "sequestration flux" (Figure 2). Once carbon is transported below the mesopelagic zone, it remains in the deep sea for 100 years or longer, hence the term "sequestration" flux. According to the modelling results of Buesseler and Boyd [26], between 1\% and $40 \%$ of the primary production is exported out of the euphotic zone, which attenuates exponentially towards the base of the mesopelagic zone and only about $1 \%$ of the surface production reaches the sea floor [27]. The export efficiency of particulate organic carbon shows regional variability. For instance, in the North Atlantic, over $40 \%$ of net primary production is exported out of the euphotic zone as compared to only $10 \%$ in the South Pacific [26], and this is driven in part by the composition of the phytoplankton community including cell size and composition (see below). Exported organic carbon is remineralized, that is, respired back to $\mathrm{CO}_{2}$ in the oceanic water column at depth, mainly by heterotrophic microbes and zooplankton (Figure 2). Thus, the biological carbon pump maintains a vertical gradient in the concentration of dissolved inorganic carbon (DIC), with higher values at increased ocean depth [28]. This deep-ocean DIC returns to the atmosphere on millennial timescales through thermohaline circulation [29].

Hugh et al. [29] expressed the efficiency of the biological pump as the amount of carbon exported from the surface layer (export production) divided by the total amount produced by photosynthesis (overall production). Modelling studies by Buesseler and Boyd [26] revealed that the overall transfer efficiency of the biological pump is determined by a combination of factors: seasonality; the composition of phytoplankton species; the fragmentation of particles by zooplankton; and the solubilization of particles by microbes. In addition, the efficiency of the biological pump is also dependent on the aggregation and disaggregation of organic-rich aggregates and interaction between POC aggregates and suspended "ballast" minerals [30]. Ballast minerals (silicate and carbonate biominerals and dust) are the major constituents of particles that leave the ocean surface via sinking. They are typically denser than seawater and most organic matter, thus, providing a large part of the density differential needed for sinking of the particles [31]. Aggregation of particles increases vertical flux by transforming small suspended particles into larger, rapidly-sinking ones. It plays an important role in the sedimentation of phytodetritus from surface layer phytoplankton blooms [21]. As illustrated by Turner [21], the vertical flux of sinking particles is mainly due to a combination of fecal pellets, marine snow and direct sedimentation of phytoplankton blooms, which are typically composed of diatoms, coccolithophorids, dinoflagellates and other plankton. Marine snow comprises macroscopic organic aggregates $>500 \mu \mathrm{m}$ in size and originates from clumps of aggregated phytoplankton (phytodetritus), discarded appendicularian houses, fecal matter and other miscellaneous detrital particles [21]. Appendicularians secrete mucous feeding structures or "houses" to collect food particles and discard and renew them up to 40 times a day [32]. Discarded appendicularian houses are highly abundant (thousands per $\mathrm{m}^{3}$ in surface waters) and are microbial hotspots with high concentrations of bacteria, ciliates, flagellates and phytoplankton. These discarded houses are therefore among the most important sources of aggregates directly produced by zooplankton in terms of carbon cycling potential [33].

The composition of the phytoplankton community in the euphotic zone largely determines the quantity and quality of organic matter that sinks to depth [27]. The main functional groups of marine phytoplankton that contribute to export production include nitrogen fixers (diazotrophic cyanobacteria), silicifiers (diatoms) and calcifiers (coccolithophores). Each of these phytoplankton groups differ in the size and composition of their cell walls and coverings, which influence their sinking velocities [17]. For example, autotrophic picoplankton $(0.2-2 \mu \mathrm{m}$ in diameter)-which include taxa such as cyanobacteria (e.g., Prochlorococcus spp. and Synechococcus spp.) and prasinophytes (various genera of eukaryotes $<2 \mu \mathrm{m}$ ) —are believed to contribute much less to carbon export from surface layers due to their small size, slow sinking velocities $(<0.5 \mathrm{~m} /$ day $)$ and rapid turnover in the microbial loop [17,34]. In contrast, larger phytoplankton cells such as diatoms (2-500 $\mu \mathrm{m}$ in diameter) are very efficient in transporting carbon to depth by forming rapidly sinking aggregates [11]. They are 
unique among phytoplankton, because they require $\mathrm{Si}$ in the form of silicic acid $\left(\mathrm{Si}(\mathrm{OH})_{4}\right)$ for growth and production of their frustules, which are made of biogenic silica $\left(\mathrm{bSiO}_{2}\right)$ and act as ballast $[17,35]$. According to the reports of Miklasz and Denny [36], the sinking velocities of diatoms can range from 0.4 to $35 \mathrm{~m} /$ day $[17,35,36]$. Analogously, coccolithophores are covered with calcium carbonate plates called 'coccoliths,' which are central to aggregation and ballasting, producing sinking velocities of nearly $5 \mathrm{~m} /$ day $[11,17]$. Although it has been assumed that picophytoplankton, characterizing vast oligotrophic areas of the ocean [27], do not contribute substantially to the particulate organic carbon (POC) flux, Richardson and Jackson [34] suggested that all phytoplankton, including picoplankton cells, contribute equally to POC export. They proposed alternative pathways for picoplankton carbon cycling, which rely on aggregation as a mechanism for both direct sinking (the export of picoplankton as POC) and mesozooplankton- or large filter feeder-mediated sinking of picoplankton-based production.

The biological pump is hypothesized to have played a significant role in atmospheric $\mathrm{CO}_{2}$ fluctuations during past glacial-interglacial periods and also responds to contemporary variations in climate. However, it is not yet clear how the biological pump will respond to future global changes in climate [21]. For such predictions to be reasonable, it is important to first decipher the response of phytoplankton, one of the key components of the biological pump to future changes in atmospheric $\mathrm{CO}_{2}$. Due to their phylogenetic diversity, different phytoplankton taxa will likely respond to climate change in different ways [17]. For instance, a decrease in the abundance of diatom is expected due to increased stratification in the future ocean [37]. Diatoms are highly efficient in transporting carbon to depths by forming large, rapidly sinking aggregates and their reduced numbers could in turn lead to decreased carbon export [11]. Also, decreased ocean $\mathrm{pH}$ due to ocean acidification may thwart the ability of coccolithophores to generate calcareous plates, potentially affecting the biological pump [17]; however, it appears that some species are more sensitive than others [38]. Thus, future changes in the relative abundance of these or other phytoplankton taxa could have a marked impact on total ocean productivity, subsequently affecting ocean biogeochemistry and carbon storage. In a recent study, Jensen et al. [39] used species distribution modelling (SDM) to predict the future global distribution of two phytoplankton species important to the biological pump: the diatom Chaetoceros diadema and the coccolithophore Emiliania huxleyi. They employed environmental data described in the Intergovernmental Panel on Climate Change's Representative Concentration Pathways scenario 8.5 (RCP 8.5), which predicts radiative forcing in the year 2100 relative to pre-industrial values. Their modelling results predicted that the total ocean area covered by C. diadema and E. huxleyi would decline by $8 \%$ and $16 \%$, respectively, under the examined climate scenario. Furthermore, they suggested that the predicted changes in the range and distribution of these two phytoplankton species under future ocean conditions, if realized, might result in their reduced contribution to carbon sequestration via the biological pump.

Because phytoplankton growth depends on temperature and is also affected by competition for light and nutrients, all of which change as atmospheric $\mathrm{CO}_{2}$ levels rise, predicting the response of phytoplankton community structure to climate change is rather complicated [40]. In the next section, we review literature to explore the effect of these concomitant changes on various parameters such as phytoplankton species and elemental composition and cell size which play important role in regulating the biological carbon pump.

\section{Phytoplankton Responses to Global Change: Influence of Cell Size, Species and Elemental Composition of Phytoplankton on the Biological Carbon Pump}

Understanding the response of phytoplankton, the key mediators of the biological pump, to changing environmental conditions is a prerequisite to predict future atmospheric concentrations of $\mathrm{CO}_{2}$. Temperature, irradiance and nutrient concentrations, along with $\mathrm{CO}_{2}$ are the chief environmental factors that influence the physiology and stoichiometry of phytoplankton [41]. The stoichiometry or elemental composition of phytoplankton is of utmost importance to secondary producers such as copepods, fish and shrimp, because it determines the nutritional quality and influences energy 
flow through the marine food chains [5]. Climate change may greatly restructure phytoplankton communities leading to cascading consequences for marine food webs, thereby altering the amount of carbon transported to the ocean interior [42].

Figure 3 gives an overview of the various environmental factors that together affect phytoplankton productivity. All of these factors are expected to undergo significant changes in the future ocean due to global change [4]. Global warming simulations predict oceanic temperature increase; dramatic changes in oceanic stratification, circulation and changes in cloud cover and sea ice, resulting in an increased light supply to the ocean surface. Also, reduced nutrient supply is predicted to co-occur with ocean acidification and warming, due to increased stratification of the water column and reduced mixing of nutrients from the deep water to the surface (Figure 1) [13].

\section{1. $\mathrm{pCO} \mathrm{C}_{2}$}

The Earth's oceans are a major sink for anthropogenic $\mathrm{CO}_{2}$ and oceanic partial pressure of $\mathrm{CO}_{2}$ $\left(\mathrm{pCO}_{2}\right)$ rises at nearly the same rate as atmospheric $\mathrm{pCO}_{2}$, thereby inducing changes in the seawater carbonate system [11]. If $\mathrm{CO}_{2}$ emissions keep rising at current rates, it is predicted that the seawater $\mathrm{pCO}_{2}$ would increase from the present value of $\sim 400$ to $800-1000 \mathrm{ppm}$ by the year 2100 [43].

\subsubsection{Ocean Carbonate System}

Once dissolved, $\mathrm{CO}_{2}$ reacts with seawater to form carbonic acid $\left(\mathrm{H}_{2} \mathrm{CO}_{3}\right)$. Oceans, however, store $\mathrm{CO}_{2}$ as dissolved inorganic carbon (DIC), which remains as dissolved $\mathrm{CO}_{2}$ and $\mathrm{H}_{2} \mathrm{CO}_{3}(1 \%)$ and the rest remains in the form of $\mathrm{HCO}_{3}{ }^{-}(\sim 90 \%)$ and $\mathrm{CO}_{3}{ }^{2-}(\sim 9 \%)$.Carbonic acid $\left[\mathrm{H}_{2} \mathrm{CO}_{3}\right]$ is a weak acid which dissociates into hydrogen ions $\left[\mathrm{H}^{+}\right]$and bicarbonate ions $\left[\mathrm{HCO}_{3}{ }^{-}\right]$. The additional hydrogen ions form bicarbonate ions by combining with carbonate ions $\left[\mathrm{CO}_{3}{ }^{2-}\right][44]$ :

$$
\begin{gathered}
{\left[\mathrm{CO}_{2}\right]+\left[\mathrm{H}_{2} \mathrm{O}\right] \rightarrow\left[\mathrm{H}_{2} \mathrm{CO}_{3}\right]} \\
{\left[\mathrm{H}_{2} \mathrm{CO}_{3}\right] \rightarrow\left[\mathrm{H}^{+}\right]+\left[\mathrm{HCO}_{3}{ }^{-}\right]} \\
{\left[\mathrm{H}^{+}\right]+\left[\mathrm{CO}_{3}{ }^{2-}\right] \rightarrow\left[\mathrm{HCO}_{3}{ }^{-}\right]}
\end{gathered}
$$

$\mathrm{CO}_{2}$ addition to seawater thus increases $\mathrm{HCO}_{3}{ }^{-}$, which brings about a decline in the ocean $\mathrm{pH}$ by increasing $\mathrm{H}^{+}$concentration [44]. Such changes in carbonate chemistry are referred to as ocean acidification, which has already led to a nearly $30 \%$ increase in seawater $\mathrm{H}^{+}$[45] and is expected to result in a mean $\mathrm{pH}$ drop from 8.2 to 7.8 by the year 2100 [43].

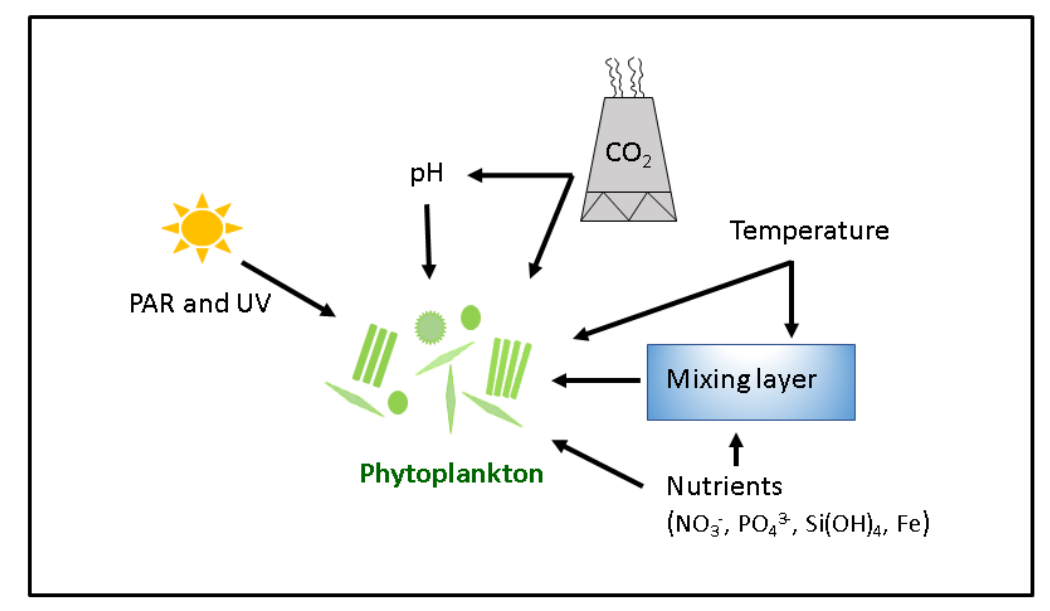

Figure 3. Overview of the various environmental factors that affect phytoplankton productivity (adapted from ref. [46]). 


\subsubsection{Role of Phytoplankton CCM}

Increased $\mathrm{CO}_{2}$ availability may benefit phytoplankton species, or they may be harmed by the $\mathrm{pH}$ decrease depending on the species, other environmental conditions or other stressors [46]. Most phytoplankton species possess an active uptake mechanism for inorganic carbon, utilizing $\mathrm{CO}_{2}$ and/or bicarbonate. Also, different species of phytoplankton have different requirements for inorganic carbon due to variation in $\mathrm{CO}_{2}$ concentrating mechanisms (CCMs) in their cells [47]. CCMs increase the concentration of $\mathrm{CO}_{2}$, surrounding the carboxylating enzyme Rubisco [43]. In the presence of a CCM, the cell may remain carbon saturated, even when ambient $\mathrm{CO}_{2}$ levels are low. Thus, it is difficult to predict the changes in photosynthetic rates of cells, which might increase (due to increased availability of the substrate and/or less energy expenditure needed to operate the CCM), decrease (due to adverse effects of low $\mathrm{pH}$ ), or remain the same under ocean acidification scenario [46]. The shift in $\mathrm{CO}_{2}: \mathrm{HCO}_{3}{ }^{-}$ratio may benefit species able to utilize only $\mathrm{CO}_{2}$ by diffusive uptake. Such species are far more likely to exhibit stimulation of growth and photosynthesis at increased oceanic $\mathrm{pCO}_{2}$, as compared to species using $\mathrm{HCO}_{3}{ }^{-}$, or taking up $\mathrm{CO}_{2}$ actively via a CCM [47]. Increased $\mathrm{CO}_{2}$ availability could potentially alter phytoplankton community composition by favoring taxa having less efficient CCMs [43]. Ambient $\mathrm{CO}_{2}$ levels can be quite variable in marine ecosystems even in the short-to mid-term [48]. Specific details of CCMs vary significantly among phytoplankton species. Certain diatom species such as Skeletonema costatum possess the ability to form intense blooms due to their capacity to overcome $C$ limitation at high population densities using an efficient CCM [45]. An efficient CCM has also been observed in some marine bloom forming dinoflagellates such as Prorocentrum minimum, Heterocapsa triquetra and Ceratium lineatum. [49]. Bloom dynamics are an important aspect of phytoplankton ecology and toxin production by harmful algal blooms can affect ecosystem services by altering food web dynamics [45]. Future elevated $\mathrm{CO}_{2}$ concentration can hinder the population densities of such a bloom forming phytoplankton species.

\subsubsection{Influence of Phytoplankton Cell Size}

Cell size is a determining factor as to whether (and how) phytoplankton ultimately respond to changes in $\mathrm{pCO}_{2}$ [50]. This is important because phytoplankton community composition strongly determines the build-up of organic matter and its potential export to deeper layers. For instance, large cells (e.g., diatoms) account for a large proportion of export production as compared to small cells (nanoand pico-plankton), which are particularly important in regions with limited nutrient availability [51]. Taucher et al. [52], in their experiments with two marine diatoms, showed that the effect of $\mathrm{CO}_{2}$ was more prominent for the large, chain-forming diatom—Dactyliosolen fragilissimus—-than for the small unicellular diatom, Thalassiosira weissflogii. Small cells have a larger surface area per unit volume than large cells and therefore can support relatively more transporters on the cell surface that facilitates diffusive uptake of $\mathrm{CO}_{2}$. In contrast, larger cells have lower surface-to-volume ratios and rely more heavily on a CCM than on diffusive $\mathrm{CO}_{2}$ uptake [52]. In a study to quantify the effect of $\mathrm{pCO}_{2}$ on the growth rate and elemental composition of five diatom species of varying diameters, Wu et al. [50] showed that the largest $\mathrm{CO}_{2}$ growth enhancement occurred in the largest diatom species, with only minor changes in the growth rate of small and medium sized diatom species. Thus, larger diatoms may be more likely to be stimulated by future increases in $\mathrm{pCO}_{2}$. These findings are consistent with the reports of Tortell et al. [53], who found a shift in phytoplankton community from small pennate diatoms (Pseudo-nitzschia subcurvata) to large chain forming centric diatoms (Chaetoceros spp.) under enhanced $\mathrm{CO}_{2}$. Because larger biomineralized phytoplankton are associated with increased and more efficient carbon export rates [54], increased population size of larger diatoms may improve the efficiency of the biological pump, due to increased carbon export to the deep ocean. 


\subsubsection{Effect of Ocean Acidification on Coccolithophores}

Among phytoplankton, coccolithophores with skeletal calcium carbonate structures are predicted to be most strongly affected due to shift in carbonate chemistry [55]. They are primarily responsible for creating and maintaining the ocean's vertical gradient in seawater alkalinity. Upper ocean alkalinity is directly affected by air/sea $\mathrm{CO}_{2}$ exchange, which is in turn modified by the formation of calcite skeletons in the surface layer and their subsequent sinking to depth. Continued acidification of surface seawater due to increased atmospheric $\mathrm{CO}_{2}$ levels changes the chemical conditions for biogenic calcification, although the outcome for different coccolithophore species is difficult to predict $[38,56,57]$. For example, certain species and strains show dissolution of coccolith structure in response to acidification while others appear more resistant to it $[38,58]$. Moreover, most strains calcify less under higher $\mathrm{CO}_{2}$ conditions, consistent with observations from the fossil record that suggest more heavily calcified cells were favored during times with reduced $\mathrm{CO}_{2}$ levels such as glacial maxima [59]. An overall reduction in pelagic calcification could lower the ratio of calcium carbonate to organic carbon in the vertical flux of biogenic material (rain ratio). This, in turn, affects the air/sea $\mathrm{CO}_{2}$ exchange, resulting in an increase in the $\mathrm{CO}_{2}$ storage capacity of the upper ocean, constituting a negative feedback to rising atmospheric $\mathrm{CO}_{2}[56]$.

\subsection{Temperature}

The mean global surface temperature across the planet has risen by $0.74{ }^{\circ} \mathrm{C}$ over the last century, with accelerated rates of warming occurring in the last 50 years $\left(0.13^{\circ} \mathrm{C}\right.$ per decade) [47]. Oceans absorb more than $90 \%$ of the extra heat energy from climate warming, raising the temperature of the ocean, particularly at high latitudes [16]. Ocean warming can affect biota directly, such as by affecting the rates of biological processes, or indirectly, such as by increasing stratification, which in turn affects nutrient supply and light availability to organisms in the mixed layers [47].

\subsubsection{Influence of Ocean Warming on Phytoplankton Community Composition}

Temperature affects phytoplankton physiology by controlling metabolic rates, such as the rate and efficiency of enzymatic reactions. Elevated temperature can increase enzymatic turnover rates (until a maximum rate is reached) through increased activity of thermally sensitive enzymes. However, while higher temperatures can increase phytoplankton metabolism, each species has a temperature maxima beyond which a sharp decline in metabolic efficiency occurs [16]. Thus, the response to ocean warming is highly species-specific in phytoplankton [52]. Because the temperature range for optimal growth is very narrow in some phytoplankton species, the predicted $2-3{ }^{\circ} \mathrm{C}$ rise in temperature [14] might affect growth and metabolic activities in phytoplankton and thereby push poorly adapted species beyond their optima. This could result in a shift in phytoplankton community composition in addition to shifts in the latitudinal distribution of the given species [47]. Such changes in community composition will likely affect the biological pump. However, it is worth mentioning that interspecific competition is a key determinant of the relative abundance of a particular species. Thus, a species may be most prevalent in an area where it does not grow under its optimum conditions. Additionally, increased stratification of the ocean's surface layer due to warming results in reduced nutrient input from below. This might result in shifts in phytoplankton community composition, such as from dominance by diatoms to coccolithophorids or from diatoms to cyanobacteria. Such shifts decrease the trophic efficiency of marine food chains by reducing the export of particulate detrital food to depth [21]. Other effects of ocean warming include a decrease in phytoplankton cell size, shifts in phenology and alterations in phytoplankton carbon cycling [52]. Several studies predict a shift towards smaller primary producers in a warmer ocean [55,60]. Flombaum et al. [61] assessed the present and future global abundances of the picoplanktonic cyanobacteria, Prochlorococcus and Synechococcus, using projections of sea surface temperature at the end of the 21st century. Their niche models suggested an increase in cell numbers of $29 \%$ and $14 \%$ for Prochlorococcus and Synechococcus, respectively, in the 
future ocean. A decline in mean cell size and numbers of larger diatoms due to ocean warming could lead to poorer feeding conditions for copepod zooplankton, resulting in less efficient energy transfer from primary to fish production [62].

\subsubsection{Effects of Ocean Warming on Organic Matter Partitioning}

As discussed in Section 2, export of particulate organic carbon (POC) is the chief determinant of the efficiency of the biological carbon pump, while only a small percentage of dissolved organic carbon (DOC) is sequestered in recalcitrant DOC molecules [22]. Ocean warming may reduce the biological drawdown of dissolved inorganic carbon (DIC) in the surface layer, resulting in increased accumulation of DOC, relative to POC, subsequently leading to reduced POC export flux through the biological pump [21]. Using an indoor-mesocosm approach, Wohlers et al. [63], showed that elevated temperature accelerates respiratory consumption of organic carbon relative to autotrophic production in a natural plankton community. Thus, a temperature increase of $2-6{ }^{\circ} \mathrm{C}$ decreased the biological drawdown of DIC in the surface layer by up to $31 \%$, subsequently shifting the partitioning of organic matter between the particulate and dissolved phase, with a greater fraction building up as dissolved material. A similar mesocosm experiment by Kim et al. [22], also supported this observation. Such changes in biogenic carbon flow might reduce the transfer of primary produced organic matter to higher trophic levels, thereby weakening the biological carbon pump and providing a positive feedback to rising atmospheric $\mathrm{CO}_{2}$ [63].

\subsubsection{Effects of Ocean Warming on Phytoplankton Stoichiometry and TEP Production}

Temperature is major determinant of stoichiometry in marine phytoplankton [64]. Yvon-Durocher et al. [64] used meta-analyses to demonstrate that variation in the N:P and C:P ratios of marine algal assemblages were significantly related to the average sea-surface temperature. They suggested that intracellular $\mathrm{P}$ was the primary factor that varied with temperature, because only the N:P and C:P ratios showed temperature dependence, while the C:N ratio did not. They attributed the observed rise in algal N:P and C:P ratios, with rising temperatures, to decline in cellular quotas of P-rich assembly machinery (ribosomes), relative to N-rich light harvesting machinery (chloroplasts and proteins), with increasing temperature. On the contrary, Martiny et al. [65], showed that thermal effect leads to increased cellular quotas of nitrogen and carbon, whereas the cellular phosphorous quota changes very little in the marine cyanobacterium, Prochlorococcus. Their results point towards other physiological acclimation mechanisms as the principal drivers of elemental changes in Prochlorococcus. They attributed the observed elemental changes to an increase in cell size, as the carbon and nitrogen cell quota increased in tandem.

Ocean warming may enhance the formation of marine snow and other organic aggregates [21]. For instance, the aggregation of marine diatoms is enhanced at higher temperatures due to an increase in the concentration of the surface-active carbohydrates-called transparent exopolymer particles (TEP) [66]. TEP form abiotically from dissolved and colloidal exopolymer carbohydrates and are abundant in marine ecosystems [67]. Increased TEP production at higher temperatures would result in increased aggregation and faster sedimentation rates, thereby strengthening the biological pump, while providing a negative feedback on increasing levels of atmospheric $\mathrm{CO}_{2}$ [21]. However, Wohlers et al. [63] observed a decrease in particulate matter concentration with increased TEP levels at rising temperatures, thus limiting the potential for TEP-mediated particle export. They suggested that the extent to which enhanced TEP production could affect particle sinking under ocean warming critically depends on the timing of TEP production along with the interplay with other biological processes such as microbial degradation and grazing.

\subsection{Irradiance}

In addition to causing acidification and warming of the ocean, global climate change also affects the penetration of light into the water column. As the euphotic layer shoals due to increased thermal 
stratification, phytoplankton will be concentrated closer to the surface where irradiance levels are higher. Additionally, penetration of photosynthetically active radiation (PAR, 400-700 nm), UV-B $(280-315 \mathrm{~nm})$ and UV-A $(315-400 \mathrm{~nm})$ radiation through surface waters would increase due to changes in cloud cover and levels of dissolved organic matter [68]. Enhanced stratification of the ocean, due to future changes in the climate, will intensify photodegradation of the colored part of dissolved inorganic matter (CDOM), which controls the penetration of UV radiation into water bodies. The resultant increase in transparency of the water column may increase the mean irradiance exposures and UV-B effects on organisms inhabiting the surface layer $[69,70]$.

Aquatic primary producers like marine phytoplankton dwell in the surface layers in order to harvest sufficient solar radiation for photosynthesis [46]. Different species have different optimal irradiances at which photosynthetic efficiency is optimal; however, photosynthetic plasticity allows cells to grow over a broader range of light levels. These include acclimation strategies such as synthesis or degradation of photosynthetic antennae, non-photochemical quenching, state transitions, activation of alternative electron pathways and sinks and other processes [71-76]. The ability of cells to cope with higher light levels depends on their irradiance optima and the acclimation strategies they employ, both of which can vary even within a species. For example, different strains of Synechococcus fall along a light preference continuum that ranges from low light to high light optimized [77]. Strains that are able to cope under higher light may come to outcompete less tolerant strains under future conditions if they are better able to avoid photoinhibition, which requires energy to repair.

\section{Effects of UV-B Radiation}

UV-B radiation can have several deleterious effects on marine primary producers: UV-B breaks proteins and cell membranes, interferes with enzymatic reactions, impairs motility and orientation and induces lesions in DNA (such as the formation of cyclobutane pyrimidine dimers) [46]. UV-B radiation can also impair accessory pigments, which funnel solar energy to the reaction centers during photosynthesis, thus inhibiting photosynthesis and growth [46,78]. However, the effects of UV radiation on phytoplankton growth rates are species specific; thus, increased UV radiation could induce changes in phytoplankton community structure [78]. For instance, Villafane et al. [79] investigated the effects of solar UV radiation on the photosynthetic rates of natural assemblages of Antarctic phytoplankton and observed an increase in diatom numbers at the expense of flagellates.

Phytoplankton employ several mechanisms to avoid damage from UV radiation. Some of these include: active vertical migration using flagella or changes in buoyancy so as to move out of zones of excessive irradiance [80,81]; production of photolyase enzymes to repair UV-damaged DNA [82] and superoxide dismutase enzymes to prevent oxidative stress [83]; synthesis of UV absorbing pigments such as scytonemin (produced by cyanobacteria to reduce the impact of UV); and production of UV screening compounds such as mycosporine-like amino acids (MAAs) [46]. Different species of phytoplankton have varying capacities to produce UV screening compounds and thus, enhanced levels of UV-B radiation can potentially result in changes in species dominance within phytoplankton communities. For instance, the bloom-forming species, Phaeocystis pouchetti, commonly present in polar waters, produces high levels of MAAs and therefore could have a competitive advantage over non-bloom forming phytoplankton species in the future. The dense, mucilaginous P. pouchetii blooms could impact the consumption of this species by herbivores, subsequently affecting other trophic levels [47]. Thus, UV-B radiation can have profound effects on trophic flow in marine ecosystems, thereafter affecting the biological pump [78].

In contrast to a decrease in the population of phytoplankton with larger cell size due to ocean warming, enhanced UV radiation is expected to facilitate the growth of large phytoplankton cells, due to an increased path length for UV radiation absorption in large cells [78]. This can in turn favor phytoplankton communities with larger cells, as observed for benthic diatoms [84]. Thus, the biological pump, driven primarily by phytoplankton in the open ocean, is limited by the quality and quantity of the solar spectrum reaching the ocean surface [68]. 


\subsection{Nutrients}

The availability of nutrients like nitrogen, phosphorous and iron limits the productivity of marine phytoplankton in the euphotic zone. The reduction in thickness of the upper mixed layer of oceans due to thermal stratification decreases nutrient availability due to reduced upward transport of nutrients from deeper layers [46].

Decreased availability of nitrogen leads to decreased chlorophyll and protein synthesis in phytoplankton cells [85]. In addition, nitrogen limitation can affect carbon fixation because of its potential effects on the levels of the carboxylating enzyme, Rubisco [5]. Therefore, reduced nutrient availability may lead to a decline in primary productivity, thereby reducing the potential export flux through the biological pump [21].

\subsubsection{Influence of Phytoplankton Nutritional Quality on Higher Trophic Levels}

Phytoplankton comprises the base of the marine food web providing organic matter (carbon, nitrogen and phosphorous) to higher trophic levels. Thus, changes in nutritional quality of marine phytoplankton (higher $\mathrm{C}: \mathrm{P}$ or $\mathrm{C}: \mathrm{N}$ ), could lead to reduced growth rates and fecundity at higher trophic levels, thereafter affecting the biological pump [43]. In their studies with the diatom, Phaeodactylum tricornutum, Li et al. [5] found the highest C:N in the cells that had been cultured under high $\mathrm{CO}_{2}$ /low nitrogen conditions, which are expected to dominate the open ocean in the near future. These synergistic effects of ocean acidification and nitrogen limitation can therefore decrease the nutritional quality of marine phytoplankton, thus influencing secondary producers and predators at higher levels [5]. For instance, the trophic transfer, assimilation and retention of key nutrients contained within phytoplankton is critical for the optimal physiological functioning of marine metazoans [43]. Large zooplankton are mainly responsible for the transfer of POC to metazoans, through fecal pellets and vertically migrating animals. However, although zooplankton fecal pellets are an important component of the biological carbon pump, much of the vertical flux of carbon is attributed to marine snow and sedimenting phytoplankton blooms that sink to the benthos without any significant contribution to pelagic food webs [21].

\subsubsection{Effects on Phytoplankton Community Composition}

Decreased nitrogen supply may also promote shifts in phytoplankton community composition by making competition for nutrients more pronounced [21,47]. Phytoplankton species possessing higher nutrient uptake efficiencies will have a competitive advantage. Diatoms, which have large cells and high nutrient requirements, are expected to be more strongly affected by reduced nutrient levels in the future [47]. In their simulations, Bopp et al. [37] showed that nutrient-depleted conditions in the surface ocean favors small phytoplankton at the expense of diatoms. Similar observations were made by Marinov et al. [40], who found a decline in diatom biomass, growth rate and abundance, with a decrease in nitrate supply over large areas in the Indian and Atlantic Ocean. Cermeno et al. [86], in their analysis of phytoplankton community composition in the Atlantic Ocean, found that the dominance of coccolithophorids rises rapidly relative to diatoms as the water column stratifies. Such alterations in phytoplankton community composition, particularly towards reduced phytoplankton cell sizes will lower storage of sinking particulate organic matter by the ocean's biological pump [8]. This can lead to reduced efficiency of the biological pump in sequestering atmospheric $\mathrm{CO}_{2}$, implying a positive feedback between climate change and the ocean carbon cycle [37]. Contrary to the above observations, Kemp and Villareal [87] showed that diatom production and the associated export of organic carbon might actually increase with higher thermal stratification and potentially act as a negative feedback to climate change. Their investigation showed that some diatoms, such as the diazotroph-associated diatom Hemiaulus hauckii, possess adaptations to stratified waters including the ability to grow in low light conditions, vertical migrations between nutricline depths and the surface and symbioses with nitrogen-fixing cyanobacteria. Such adaptations facilitate the maintenance of diatom seed populations 
that may then exploit mixing events even in oligotrophic oceanic waters. Formation of aggregates by such diatoms promotes rapid settling, subsequently enhancing the export flux of carbon to depths.

\subsubsection{Effects of Stratification on Coastal Upwelling Regions}

Coastal upwelling regions such as those located along the eastern boundaries of the Pacific and Atlantic Ocean basins, make a major contribution to the productivity of the ocean [88]. Changes in ocean circulation and stratification are predicted to increase the flux of nitrate during upwelling events in these regions [89]. Rykaczewski et al. [90], in their studies of the California Current Ecosystem, attributed the increased nitrate flux to decreased ventilation of the Pacific Ocean and the associated accumulation of nitrate in deep waters. A series of incubation experiments in coastal California showed that increased nitrate availability relative to iron favored slower sinking single-celled diatoms over faster sinking chain-forming diatoms [89]. Hence, changing nutrient supply ratios have the potential to affect trophic structure and the biological carbon and silicate pumps in coastal upwelling regions by shifting the chain forming behavior of phytoplankton.

\subsubsection{Trace Metal Micronutrient Availability}

The effect of climate change on the availability of trace metal micronutrients like iron is an area of research that is rapidly expanding. The mesocosm experiments of Breitbarth et al. [91] indicated that ocean acidification may result in increased iron bioavailability due to an enhanced fraction of dissolved iron and elevated Fe (II) concentrations in coastal systems, fueling increased phytoplankton carbon acquisition and export. However, it has also been proposed that ocean acidification could decrease Fe availability by stabilizing Fe ligands, leading to lower Fe uptake rates by phytoplankton [92]. Ocean acidification is expected to affect the redox speciation of copper, yielding an enhanced $\mathrm{Cu}$ (I) fraction. However, the biological implications thereof are largely unknown [93]. Iron limits productivity in approximately $30 \%$ of the world's oceans [94,95] and drives the evolution of phytoplankton photosynthetic traits [96], hence factors that affect iron supply and recycling rates will directly affect the biological pump and phytoplankton adaptation potential. The main source of iron to the ocean is via atmospheric transport and deposition of terrigenous and anthropogenic aerosol particles. Potential expansion of desert regions could increase the flux of aerosol iron in certain areas of the ocean and shift the patterns of nutrient limitation. Supply of aerosol metals has been shown to cause changes in phytoplankton community structure in numerous incubation experiments [97,98], which in turn has the potential to alter productivity and export rates.

\section{Conclusions and Future Directions}

The ocean is among the largest reservoirs of carbon on Earth; hence, quantifying the efficiency of the biological carbon pump in the face of climate change is a prerequisite to predict future atmospheric $\mathrm{CO}_{2}$ concentrations. It is evident from literature reports that the strength of the biological pump will likely change in the future ocean, in response to a changing climate. However, predicting the direction of such change is difficult owing to the complexity of the problem. Numerous contrasts arise from comparisons of different geographical areas, ecosystems, environmental conditions and organisms. For instance, larger phytoplankton such as diatoms are likely to be stimulated under future elevated $\mathrm{CO}_{2}$ and light levels, resulting in increased carbon export to the deep ocean. On the other hand, ocean warming and future nutrient-depleted conditions would favor the growth of smaller phytoplankton, such as picoplanktonic cyanobacteria, leading to reduced efficiency of the biological pump. This makes it difficult to currently predict whether the biological pump will strengthen or weaken in the next 100 years. Moreover, the simultaneous alterations of oceanic carbonate system, temperature, light and nutrient availability due to global change will vary in different regions of the ocean [21] and may have synergistic or antagonistic effects on phytoplankton. Because the efficiency of the biological pump is a function of phytoplankton physiology and community structure, it is important to understand how concurrent multiple stressors (including changes in temperature, light 
intensity, nutrients and $\mathrm{CO}_{2}$ levels) affect growth rates and competition between phytoplankton species [45]. This further increases complexity, because the number of treatment combinations grows exponentially with each added stressor [99]. To date, few studies have probed the combined effects of $\mathrm{CO}_{2}$, temperature and nutrient levels on phytoplankton. Most of them have focused on nitrogen fixing cyanobacteria because the factors that drive their abundance are already known and well characterized. These experiments identified many interactive effects, including the unexpected finding that while enhanced $\mathrm{CO}_{2}$ generally increases $\mathrm{N}_{2}$ fixation under nutrient replete conditions, it actually decreases fixation when iron is limiting [100]. Future studies should evaluate multiple species and strains of phytoplankton and incorporate multiple stressor treatments to understand the full range of potential effects [99]. Also, the complexity of the role that the marine food web plays in the biological pump and its high spatial and temporal variability makes global generalizations difficult [11]. Future studies should address this issue along with the effects of interspecies activities such as competition and predation loss on the biological carbon pump.

An additional limitation at present is that majority of the ocean acidification studies have investigated responses in phytoplankton cells acclimated to changing environmental conditions over time scales too short for evolution to produce major changes [45]. Using a global marine ecosystem model, Dutkiewicz et al. [101] suggested that longer timescales of competition- and transport-mediated adjustments are necessary for predicting the changes to the phytoplankton community structure. In addition, experimental evolution with cultured phytoplankton is an important next step in predicting how major phytoplankton taxa will respond to climate change $[17,45]$. Such studies are in turn essential to gain insight on the biological carbon pump and the ability of the ocean to act as a long-term sink for atmospheric $\mathrm{CO}_{2}$.

Acknowledgments: The authors thank three anonymous reviewers for their comments on the manuscript. This work was supported by a Clare Boothe Luce endowment, an Alfred P Sloan Research Fellowship in Ocean Sciences and the Marion Milligan Mason Award for Women in the Chemical Sciences from AAAS to KRMM.

Author Contributions: Samarpita Basu and Katherine R. M. Mackey conceived of the topic and jointly contributed to the writing and editing of the manuscript.

Conflicts of Interest: The authors declare no conflict of interest.

\section{References}

1. Baumert, H.Z.; Petzoldt, T. The role of temperature, cellular quota and nutrient concentrations for photosynthesis, growth and light-dark acclimation in phytoplankton. Limnologica 2008, 38, 313-326. [CrossRef]

2. Simon, N.; Cras, A.-L.; Foulon, E.; Lemée, R. Diversity and evolution of marine phytoplankton. C. R. Biol. 2009, 332, 159-170. [CrossRef] [PubMed]

3. Lam, M.K.; Lee, K.T.; Mohamed, A.R. Current status and challenges on microalgae-based carbon capture. Int. J. Greenh. Gas Control 2012, 10, 456-469. [CrossRef]

4. Hader, D.P.; Villafane, V.E.; Helbling, E.W. Productivity of aquatic primary producers under global climate change. Photochem. Photobiol. Sci. 2014, 13, 1370-1392. [CrossRef] [PubMed]

5. Li, W.; Gao, K.S.; Beardall, J. Interactive effects of ocean acidification and nitrogen-limitation on the diatom phaeodactylum tricornutum. PLoS ONE 2012, 7, e51590. [CrossRef] [PubMed]

6. Hulse, D.; Arndt, S.; Wilson, J.D.; Munhoven, G.; Ridgwell, A. Understanding the causes and consequences of past marine carbon cycling variability through models. Earth-Sci. Rev. 2017, 171, 349-382. [CrossRef]

7. Chisholm, S.W. The iron hypothesis: Basic research meets environmental policy. Rev. Geophys. 1995, 33, 1277-1286. [CrossRef]

8. Hutchins, D.A.; Fu, F. Microorganisms and ocean global change. Nat. Microbiol. 2017, 2, 17058. [CrossRef] [PubMed]

9. Sanders, R.; Henson, S.A.; Koski, M.; De la Rocha, C.L.; Painter, S.C.; Poulton, A.J.; Riley, J.; Salihoglu, B.; Visser, A.; Yool, A.; et al. The biological carbon pump in the north Atlantic. Prog. Oceanogr. 2014, 129, 200-218. [CrossRef] 
10. Boyd, P.W. Toward quantifying the response of the oceans' biological pump to climate change. Front. Mar. Sci. 2015, 2. [CrossRef]

11. Passow, U.; Carlson, C.A. The biological pump in a high $\mathrm{CO}_{2}$ world. Mar. Ecol. Prog. Ser. 2012, 470, $249-271$. [CrossRef]

12. Bhadury, P. Effects of ocean acidification on marine invertebrates-A review. Indian J. Geo-Mar. Sci. 2015, 44, 454-464.

13. Sarmiento, J.L.; Slater, R.; Barber, R.; Bopp, L.; Doney, S.C.; Hirst, A.C.; Kleypas, J.; Matear, R.; Mikolajewicz, U.; Monfray, P.; et al. Response of ocean ecosystems to climate warming. Glob. Biogeochem. Cycle 2004, 18. [CrossRef]

14. Pachauri, R.K.; Reisinger, A. Climate Change 2007 Synthesis Report Contribution of Working Groups I, II and III to the Fourth Assessment Report of the Intergovernmental Panel on Climate Change; Intergovernmental Panel on Climate Change (IPCC): Geneva, Switzerland, 2007.

15. Riebesell, U.; Schulz, K.G.; Bellerby, R.G.; Botros, M.; Fritsche, P.; Meyerhofer, M.; Neill, C.; Nondal, G.; Oschlies, A.; Wohlers, J.; et al. Enhanced biological carbon consumption in a high $\mathrm{CO}_{2}$ ocean. Nature 2007, 450, 545-548. [CrossRef] [PubMed]

16. Petrou, K.; Kranz, S.A.; Trimborn, S.; Hassler, C.S.; Ameijeiras, S.B.; Sackett, O.; Ralph, P.J.; Davidson, A.T. Southern ocean phytoplankton physiology in a changing climate. J. Plant Physiol. 2016, 203, 135-150. [CrossRef] [PubMed]

17. Collins, S.; Rost, B.; Rynearson, T.A. Evolutionary potential of marine phytoplankton under ocean acidification. Evolut. Appl. 2014, 7, 140-155. [CrossRef] [PubMed]

18. Finkel, Z.V.; Beardall, J.; Flynn, K.J.; Quigg, A.; Rees, T.A.V.; Raven, J.A. Phytoplankton in a changing world: Cell size and elemental stoichiometry. J. Plankton Res. 2010, 32, 119-137. [CrossRef]

19. Bishop, J.K.B. Autonomous observations of the ocean biological carbon pump. Oceanography 2009, 22, 182-193. [CrossRef]

20. Falkowski, P.; Scholes, R.J.; Boyle, E.; Canadell, J.; Canfield, D.; Elser, J.; Gruber, N.; Hibbard, K.; Hogberg, P.; Linder, S.; et al. The global carbon cycle: A test of our knowledge of earth as a system. Science 2000, 290, 291-296. [CrossRef] [PubMed]

21. Turner, J.T. Zooplankton fecal pellets, marine snow, phytodetritus and the ocean's biological pump. Prog. Oceanogr. 2015, 130, 205-248. [CrossRef]

22. Kim, J.M.; Lee, K.; Shin, K.; Yang, E.J.; Engel, A.; Karl, D.M.; Kim, H.C. Shifts in biogenic carbon flow from particulate to dissolved forms under high carbon dioxide and warm ocean conditions. Geophys. Res. Lett. 2011, 38. [CrossRef]

23. Hansell, D.A.; Carlson, C.A.; Repeta, D.J.; Schlitzer, R. Dissolved organic matter in the ocean a controversy stimulates new insights. Oceanography 2009, 22, 202-211. [CrossRef]

24. Carlson, C.A.; Ducklow, H.W.; Michaels, A.F. Annual flux of dissolved organic-carbon from the euphotic zone in the northwestern Sargasso Sea. Nature 1994, 371, 405-408. [CrossRef]

25. Roshan, S.; DeVries, T. Efficient dissolved organic carbon production and export in the oligotrophic ocean. Nat. Commun. 2017, 8, 2036. [CrossRef] [PubMed]

26. Buesseler, K.O.; Boyd, P.W. Shedding light on processes that control particle export and flux attenuation in the twilight zone of the open ocean. Limnol. Oceanogr. 2009, 54, 1210-1232. [CrossRef]

27. Herndl, G.J.; Reinthaler, T. Microbial control of the dark end of the biological pump. Nat. Geosci. 2013, 6, 718-724. [CrossRef] [PubMed]

28. Hofmann, M.; Schellnhuber, H.J. Oceanic acidification affects marine carbon pump and triggers extended marine oxygen holes. Proc. Natl. Acad. Sci. USA 2009, 106, 3017-3022. [CrossRef] [PubMed]

29. Ducklow, H.W.; Steinberg, D.K.; Buesseler, K.O. Upper ocean carbon export and the biological pump. Oceanography 2001, 14. [CrossRef]

30. De La Rocha, C.L.; Passow, U. Factors influencing the sinking of POC and the efficiency of the biological carbon pump. Deep Sea Res. Part II Top. Stud. Oceanogr. 2007, 54, 639-658. [CrossRef]

31. Armstrong, R.A.; Lee, C.; Hedges, J.I.; Honjo, S.; Wakeham, S.G. A new, mechanistic model for organic carbon fluxes in the ocean based on the quantitative association of POC with ballast minerals. Deep Sea Res. Part II Top. Stud. Oceanogr. 2001, 49, 219-236. [CrossRef]

32. Sato, R.; Tanaka, Y.; Ishimaru, T. Species-specific house productivity of appendicularians. Mar. Ecol. Prog. Ser. 2003, 259, 163-172. [CrossRef] 
33. Nishibe, Y.; Takahashi, K.; Ichikawa, T.; Hidaka, K.; Kurogi, H.; Segawa, K.; Saito, H. Degradation of discarded appendicularian houses by oncaeid copepods. Limnol. Oceanogr. 2015, 60, 967-976. [CrossRef]

34. Richardson, T.L.; Jackson, G.A. Small phytoplankton and carbon export from the surface ocean. Science 2007, 315, 838-840. [CrossRef] [PubMed]

35. Ragueneau, O.; Schultes, S.; Bidle, K.; Claquin, P.; Moriceau, B. Si and c interactions in the world ocean: Importance of ecological processes and implications for the role of diatoms in the biological pump. Glob. Biogeochem. Cycle 2006, 20. [CrossRef]

36. Miklasz, K.A.; Denny, M.W. Diatom sinking speeds: Improved predictions and insight from a modified stokes' law. Limnol. Oceanogr. 2010, 55, 2513-2525. [CrossRef]

37. Bopp, L.; Aumont, O.; Cadule, P.; Alvain, S.; Gehlen, M. Response of diatoms distribution to global warming and potential implications: A global model study. Geophys. Res. Lett. 2005, 32. [CrossRef]

38. Iglesias-Rodriguez, M.D.; Halloran, P.R.; Rickaby, R.E.M.; Hall, I.R.; Colmenero-Hidalgo, E.; Gittins, J.R.; Green, D.R.H.; Tyrrell, T.; Gibbs, S.J.; von Dassow, P.; et al. Phytoplankton calcification in a high- $\mathrm{CO}_{2}$ world. Science 2008, 320, 336-340. [CrossRef] [PubMed]

39. Jensen, L.O.; Mousing, E.A.; Richardson, K. Using species distribution modelling to predict future distributions of phytoplankton: Case study using species important for the biological pump. Mar. Ecol.-Evol. Perspect. 2017, 38, e12427. [CrossRef]

40. Marinov, I.; Doney, S.C.; Lima, I.D. Response of ocean phytoplankton community structure to climate change over the 21st century: Partitioning the effects of nutrients, temperature and light. Biogeosciences 2010, 7, 3941-3959. [CrossRef]

41. Moreno, A.R.; Hagstrom, G.I.; Primeau, F.W.; Levin, S.A.; Martiny, A.C. Marine phytoplankton stoichiometry mediates nonlinear interactions between nutrient supply, temperature, and atmospheric $\mathrm{CO}_{2}$. Biogeosci. Discuss. 2017, 2017, 1-28. [CrossRef]

42. Irwin, A.J.; Finkel, Z.V.; Muller-Karger, F.E.; Ghinaglia, L.T. Phytoplankton adapt to changing ocean environments. Proc. Natl. Acad. Sci. USA 2015, 112, 5762-5766. [CrossRef] [PubMed]

43. King, A.L.; Jenkins, B.D.; Wallace, J.R.; Liu, Y.; Wikfors, G.H.; Milke, L.M.; Meseck, S.L. Effects of $\mathrm{CO}_{2}$ on growth rate, C:N:P, and fatty acid composition of seven marine phytoplankton species. Mar. Ecol. Prog. Ser. 2015, 537, 59-69. [CrossRef]

44. Das, S.; Mangwani, N. Ocean acidification and marine microorganisms: Responses and consequences. Oceanologia 2015, 57, 349-361. [CrossRef]

45. Mackey, K.R.M.; Morris, J.J.; Morel, F.M.M.; Kranz, S.A. Response of photosynthesis to ocean acidification. Oceanography 2015, 28, 74-91. [CrossRef]

46. Häder, D.-P.; Gao, K. Interactions of anthropogenic stress factors on marine phytoplankton. Front. Environ. Sci. 2015, 3. [CrossRef]

47. Beardall, J.; Stojkovic, S.; Larsen, S. Living in a high $\mathrm{CO}_{2}$ world: Impacts of global climate change on marine phytoplankton. Plant Ecol. Divers. 2009, 2, 191-205. [CrossRef]

48. Mercado, J.M.; Gordillo, F.J.L. Inorganic carbon acquisition in algal communities: Are the laboratory data relevant to the natural ecosystems? Photosynth. Res. 2011, 109, 257-267. [CrossRef] [PubMed]

49. Rost, B.; Richter, K.U.; Riebesell, U.; Hansen, P.J. Inorganic carbon acquisition in red tide dinoflagellates. Plant Cell Environ. 2006, 29, 810-822. [CrossRef] [PubMed]

50. Wu, Y.; Campbell, D.A.; Irwin, A.J.; Suggett, D.J.; Finkel, Z.V. Ocean acidification enhances the growth rate of larger diatoms. Limnol. Oceanogr. 2014, 59, 1027-1034. [CrossRef]

51. Gazeau, F.; Salon, A.; Pitta, P.; Tsiola, A.; Maugendre, L.; Giani, M.; Celussi, M.; Pedrotti, M.L.; Marro, S.; Guieu, C. Limited impact of ocean acidification on phytoplankton community structure and carbon export in an oligotrophic environment: Results from two short-term mesocosm studies in the mediterranean sea. Estuar. Coast. Shelf Sci. 2017, 186, 72-88. [CrossRef]

52. Taucher, J.; Jones, J.; James, A.; Brzezinski, M.A.; Carlson, C.A.; Riebesell, U.; Passow, U. Combined effects of $\mathrm{CO}_{2}$ and temperature on carbon uptake and partitioning by the marine diatoms thalassiosira weissflogii and dactyliosolen fragilissimus. Limnol. Oceanogr. 2015, 60, 901-919. [CrossRef]

53. Tortell, P.D.; Payne, C.D.; Li, Y.; Trimborn, S.; Rost, B.; Smith, W.O.; Riesselman, C.; Dunbar, R.B.; Sedwick, P.; DiTullio, G.R. $\mathrm{CO}_{2}$ sensitivity of southern ocean phytoplankton. Geophys. Res. Lett. 2008, 35, L04605. [CrossRef] 
54. Fischer, G.; Karakaş, G. Sinking rates and ballast composition of particles in the Atlantic Ocean: Implications for the organic carbon fluxes to the deep ocean. Biogeosciences 2009, 6, 85-102. [CrossRef]

55. Sommer, U.; Paul, C.; Moustaka-Gouni, M. Warming and ocean acidification effects on phytoplankton-from species shifts to size shifts within species in a mesocosm experiment. PLoS ONE 2015, 10. [CrossRef] [PubMed]

56. Rost, B.; Riebesell, U. Coccolithophores and the biological pump: Responses to environmental changes. In Coccolithophores: From Molecular Processes to Global Impact; Springer: Berlin/Heidelberg, Germany, 2004; pp. 99-125.

57. Fabry, V.J. Ocean science. Marine calcifiers in a high- $\mathrm{CO}_{2}$ ocean. Science 2008, 320, 1020-1022. [CrossRef] [PubMed]

58. O'dea, S.A.; Gibbs, S.J.; Bown, P.R.; Young, J.R.; Poulton, A.J.; Newsam, C.; Wilson, P.A. Coccolithophore calcification response to past ocean acidification and climate change. Nat. Commun. 2014, 5. [CrossRef] [PubMed]

59. Beaufort, L.; Probert, I.; de Garidel-Thoron, T.; Bendif, E.M.; Ruiz-Pino, D.; Metzl, N.; Goyet, C.; Buchet, N.; Coupel, P.; Grelaud, M.; et al. Sensitivity of coccolithophores to carbonate chemistry and ocean acidification. Nature 2011, 476, 80-83. [CrossRef] [PubMed]

60. Moran, X.A.G.; Lopez-Urrutia, A.; Calvo-Diaz, A.; Li, W.K.W. Increasing importance of small phytoplankton in a warmer ocean. Glob. Chang. Biol. 2010, 16, 1137-1144. [CrossRef]

61. Flombaum, P.; Gallegos, J.L.; Gordillo, R.A.; Rincon, J.; Zabala, L.L.; Jiao, N.A.Z.; Karl, D.M.; Li, W.K.W.; Lomas, M.W.; Veneziano, D.; et al. Present and future global distributions of the marine cyanobacteria prochlorococcus and synechococcus. Proc. Natl. Acad. Sci. USA 2013, 110, 9824-9829. [CrossRef] [PubMed]

62. Sommer, U.; Lengfellner, K. Climate change and the timing, magnitude, and composition of the phytoplankton spring bloom. Glob. Chang. Biol. 2008, 14, 1199-1208. [CrossRef]

63. Wohlers, J.; Engel, A.; Zollner, E.; Breithaupt, P.; Jurgens, K.; Hoppe, H.G.; Sommer, U.; Riebesell, U. Changes in biogenic carbon flow in response to sea surface warming. Proc. Natl. Acad. Sci. USA 2009, 106, 7067-7072. [CrossRef] [PubMed]

64. Yvon-Durocher, G.; Dossena, M.; Trimmer, M.; Woodward, G.; Allen, A.P. Temperature and the biogeography of algal stoichiometry. Glob. Ecol. Biogeogr. 2015, 24, 562-570. [CrossRef]

65. Martiny, A.C.; Ma, L.Y.; Mouginot, C.; Chandler, J.W.; Zinser, E.R. Interactions between thermal acclimation, growth rate, and phylogeny influence Prochlorococcus elemental stoichiometry. PLoS ONE 2016, 11. [CrossRef] [PubMed]

66. Piontek, J.; Handel, N.; Langer, G.; Wohlers, J.; Riebesell, U.; Engel, A. Effects of rising temperature on the formation and microbial degradation of marine diatom aggregates. Aquat. Microb. Ecol. 2009, 54, 305-318. [CrossRef]

67. Engel, A. Direct relationship between $\mathrm{CO}_{2}$ uptake and transparent exopolymer particles production in natural phytoplankton. J. Plankton Res. 2002, 24, 49-53. [CrossRef]

68. Beardall, J.; Sobrino, C.; Stojkovic, S. Interactions between the impacts of ultraviolet radiation, elevated $\mathrm{CO}_{2}$, and nutrient limitation on marine primary producers. Photochem. Photobiol. Sci. 2009, 8, 1257-1265. [CrossRef] [PubMed]

69. Zepp, R.G.; Erickson, D.J., III; Paul, N.D.; Sulzberger, B. Interactive effects of solar UV radiation and climate change on biogeochemical cycling. Photochem. Photobiol. Sci. 2007, 6, 286-300. [CrossRef] [PubMed]

70. Caron, D.A.; Hutchins, D.A. The effects of changing climate on microzooplankton grazing and community structure: Drivers, predictions and knowledge gaps. J. Plankton Res. 2013, 35, 235-252. [CrossRef]

71. Bibby, T.S.; Mary, I.; Nield, J.; Partensky, F.; Barber, J. Low-light-adapted Prochlorococcus species possess specific antennae for each photosystem. Nature 2003, 424, 1051-1054. [CrossRef] [PubMed]

72. Kirilovsky, D.; Kerfeld, C.A. The orange carotenoid protein in photoprotection of photosystem II in cyanobacteria. Biochim. Biophys. Acta 2012, 1817, 158-166. [CrossRef] [PubMed]

73. Biggins, J.; Bruce, D. Regulation of excitation-energy transfer in organisms containing phycobilins. Photosynth. Res. 1989, 20, 1-34. [CrossRef] [PubMed]

74. Mackey, K.R.M.; Paytan, A.; Grossman, A.R.; Bailey, S. A photosynthetic strategy for coping in a high-light, low-nutrient environment. Limnol. Oceanogr. 2008, 53, 900-913. [CrossRef]

75. Bailey, S.; Grossman, A. Photoprotection in cyanobacteria: Regulation of light harvesting. Photochem. Photobiol. 2008, 84, 1410-1420. [CrossRef] [PubMed] 
76. Bibby, T.S.; Nield, J.; Barber, J. Iron deficiency induces the formation of an antenna ring around trimeric photosystem I in cyanobacteria. Nature 2001, 412, 743-745. [CrossRef] [PubMed]

77. Mackey, K.R.M.; Post, A.F.; McIlvin, M.R.; Saito, M.A. Physiological and proteomic characterization of light adaptations in marine synechococcus. Environ. Microbiol. 2017, 19, 2348-2365. [CrossRef] [PubMed]

78. Beardall, J.; Stojkovic, S. Microalgae under global environmental change: Implications for growth and productivity, populations and trophic flow. ScienceAsia 2006, 32, 1-10. [CrossRef]

79. Villafane, V.E.; Helbling, E.W.; HolmHansen, O.; Chalker, B.E. Acclimatization of Antarctic natural phytoplankton assemblages when exposed to solar ultraviolet radiation. J. Plankton Res. 1995, 17, 2295-2306. [CrossRef]

80. Overmann, J.; Pfennig, N. Bouyancy regulation and aggregate formation in Amoebobacter purpureus from Mahoney Lake. FEMS Microbiol. Lett. 1992, 101, 67-79. [CrossRef]

81. Ma, Z.L.; Gao, K.S. Photosynthetically active and UV radiation act in an antagonistic way in regulating buoyancy of Arthrospira (Spirulina) platensis (cyanobacterium). Environ. Exp. Bot. 2009, 66, 265-269. [CrossRef]

82. Ng, W.O.; Zentella, R.; Wang, Y.S.; Taylor, J.S.A.; Pakrasi, H.B. PhrA, the major photoreactivating factor in the cyanobacterium Synechocystis sp. strain PCC 6803 codes for a cyclobutane-pyrimidine-dimer-specific DNA photolyase. Arch. Microbiol. 2000, 173, 412-417. [CrossRef] [PubMed]

83. Wolfe-Simon, F.; Grzebyk, D.; Schofield, O.; Falkowski, P.G. The role and evolution of superoxide dismutases in algae. J. Phycol. 2005, 41, 453-465. [CrossRef]

84. Bothwell, M.L.; Sherbot, D.; Roberge, A.C.; Daley, R.J. Influence of natural ultraviolet-radiation on lotic periphytic diatom community growth, biomass accrual, and species composition: Short-term versus long-term effects. J. Phycol. 1993, 29, 24-35. [CrossRef]

85. Hipkin, C.R.; Thomas, R.J.; Syrett, P.J. Effects of nitrogen deficiency on nitrate reductase, nitrate assimilation and photosynthesis in unicellular marine-algae. Mar. Biol. 1983, 77, 101-105. [CrossRef]

86. Cermeno, P.; Dutkiewicz, S.; Harris, R.P.; Follows, M.; Schofield, O.; Falkowski, P.G. The role of nutricline depth in regulating the ocean carbon cycle. Proc. Natl. Acad. Sci. USA 2008, 105, 20344-20349. [CrossRef] [PubMed]

87. Kemp, A.E.S.; Villareal, T.A. High diatom production and export in stratified waters-A potential negative feedback to global warming. Prog. Oceanogr. 2013, 119, 4-23. [CrossRef]

88. Capone, D.G.; Hutchins, D.A. Microbial biogeochemistry of coastal upwelling regimes in a changing ocean. Nat. Geosci. 2013, 6, 711-717. [CrossRef]

89. Mackey, K.R.M.; Chien, C.T.; Paytan, A. Microbial and biogeochemical responses to projected future nitrate enrichment in the California upwelling system. Front. Microbiol. 2014, 5. [CrossRef] [PubMed]

90. Rykaczewski, R.R.; Dunne, J.P. Enhanced nutrient supply to the California current ecosystem with global warming and increased stratification in an earth system model. Geophys. Res. Lett. 2010, 37. [CrossRef]

91. Breitbarth, E.; Bellerby, R.J.; Neill, C.C.; Ardelan, M.V.; Meyerhofer, M.; Zollner, E.; Croot, P.L.; Riebesell, U. Ocean acidification affects iron speciation during a coastal seawater mesocosm experiment. Biogeosciences 2010, 7, 1065-1073. [CrossRef]

92. Shi, D.L.; Xu, Y.; Hopkinson, B.M.; Morel, F.M.M. Effect of ocean acidification on iron availability to marine phytoplankton. Science 2010, 327, 676-679. [CrossRef] [PubMed]

93. Hoffmann, L.J.; Breitbarth, E.; Boyd, P.W.; Hunter, K.A. Influence of ocean warming and acidification on trace metal biogeochemistry. Mar. Ecol. Prog. Ser. 2012, 470, 191-205. [CrossRef]

94. Moore, J.K.; Doney, S.C.; Glover, D.M.; Fung, I.Y. Iron cycling and nutrient-limitation patterns in surface waters of the world ocean. Deep Sea Res. Part II Top. Stud. Oceanogr. 2002, 49, 463-507. [CrossRef]

95. Moore, C.M.; Mills, M.M.; Arrigo, K.R.; Berman-Frank, I.; Bopp, L.; Boyd, P.W.; Galbraith, E.D.; Geider, R.J.; Guieu, C.; Jaccard, S.L.; et al. Processes and patterns of oceanic nutrient limitation. Nat. Geosci. 2013, 6, 701-710. [CrossRef]

96. Mackey, K.R.M.; Post, A.F.; McIlvin, M.R.; Cutter, G.A.; John, S.G.; Saito, M.A. Divergent responses of atlantic coastal and oceanic synechococcus to iron limitation. Proc. Natl. Acad. Sci. USA 2015, 112, 9944-9949. [CrossRef] [PubMed]

97. Mackey, K.R.M.; Buck, K.N.; Casey, J.R.; Cid, A.; Lomas, M.W.; Sohrin, Y.; Paytan, A. Phytoplankton responses to atmospheric metal deposition in the coastal and open-ocean Sargasso sea. Front. Microbiol. 2012, 3. [CrossRef] [PubMed] 
98. Mahowald, N.M.; Hamilton, D.S.; Mackey, K.R.M.; Moore, J.K.; Baker, A.R.; Scanza, R.A.; Zhang, Y. Aerosol trace metal deposition dissolution and impacts on marine microorganisms and biogeochemistry. Nat. Commun. 2018, in press.

99. Andersson, A.J.; Kline, D.I.; Edmunds, P.J.; Archer, S.D.; Bednaršek, N.; Carpenter, R.C.; Chadsey, M.; Goldstein, P.; Grottoli, A.G.; Hurst, T.P.; et al. Understanding ocean acidification impacts on organismal to ecological scales. Oceanography 2015, 28, 16-27. [CrossRef]

100. Shi, D.; Kranz, S.A.; Kim, J.M.; Morel, F.M. Ocean acidification slows nitrogen fixation and growth in the dominant diazotroph trichodesmium under low-iron conditions. Proc. Natl. Acad. Sci. USA 2012, 109, E3094-E3100. [CrossRef] [PubMed]

101. Dutkiewicz, S.; Morris, J.J.; Follows, M.J.; Scott, J.; Levitan, O.; Dyhrman, S.T.; Berman-Frank, I. Impact of ocean acidification on the structure of future phytoplankton communities. Nat. Clim. Chang. 2015, 5, 1002-1006. [CrossRef]

(C) 2018 by the authors. Licensee MDPI, Basel, Switzerland. This article is an open access article distributed under the terms and conditions of the Creative Commons Attribution (CC BY) license (http://creativecommons.org/licenses/by/4.0/). 